\title{
R\&D Investment and Idiosyncratic Risk: Evidence from China
}

\author{
Shiqi Li \\ National University of Singapore, Faculty of Arts \& Social \\ Sciences \\ lishiqi@u.nus.edu
}

\begin{abstract}
We investigate the influence of research and development (R\&D) investment on firms' idiosyncratic risk. We find that firms' R\&D investment has a negative relationship with firms' idiosyncratic risk. This relationship is proved to be robust according to several robustness tests including replacing $\mathrm{RD}$ variable with its logarithm and adding lag terms. Further analysis demonstrates that the effect of R\&D investment on firms' idiosyncratic risk is more pronounced in firms with lower market capitalization, non-state owned, lower leverage and non-Big 4 auditing. Moreover, our findings provide support to the notion that R\&D investment can push firms' innovation to further increase the diversification of the product and reduce their idiosyncratic risk. This conclusion also calls on the government to introduce new policies to encourage firms' $R \& D$ investment.
\end{abstract}

\section{CCS CONCEPTS}

- General and reference $\rightarrow$ Document types; General conference proceedings.

\section{KEYWORDS}

Research and Development, Idiosyncratic risk, Chinese firms,

\section{ACM Reference Format:}

Shiqi Li and Shixin Ma. 2021. R\&D Investment and Idiosyncratic Risk: Evidence from China. In The 2021 12th International Conference on E-business, Management and Economics (ICEME 2021), July 17-19, 2021, Beijing, China. ACM, New York, NY, USA, 7 pages. https://doi.org/10.1145/3481127.3481223

\section{INTRODUCTION}

In order to survive and develop, it is necessary to constantly update products so that firms can always follow the trends for that time and ensure products always meet the needs of consumers. This is also integral in driving the development of the core competitiveness of firms [1]. The product development process is inseparable from the firm's attention to Research and Development (R\&D) investment. Only by making $R \& D$ a priority can it be in a leading position in technological innovation and development [2]. Unlike in prior research, the objective of this paper is to investigate the effects of R\&D on the idiosyncratic risk of Chinese firms. By analyzing the data from the market, our work is able to precisely infer the outcome of a company's investment into innovation and unsystematic risks.

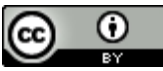

This work is licensed under a Creative Commons Attribution International 4.0 License.

ICEME 2021, fuly 17-19, 2021, Beijing, China

(C) 2021 Copyright held by the owner/author(s).

ACM ISBN 978-1-4503-9006-4/21/07.

https://doi.org/10.1145/3481127.3481223

\author{
Shixin Ma \\ The University of Hong Kong, HKU Business School \\ u3553333@connect.hku.hk
}

Based on the results, the conclusion of this paper is that, increasing investment into innovation can reduce a firm's idiosyncratic risks.

Idiosyncratic risk has a great influence on firms' future development. When firms' idiosyncratic risk increases, the firm-specific uncertainty will increase. Since it is widely accepted that most managers are risk -averse, they may underinvest when firms' idiosyncratic increases which will undoubtedly affect firms' financial condition [3]. The work [3] have explored factors that may affect firms' idiosyncratic risk which is investment for publicly traded firms in the United States has a negative effect on firms' idiosyncratic risk [3]. Moreover, corporate social performance (CSP) can also reduce firms' idiosyncratic risk [4]. Mishra et al. even did more research on the impact of CSP and found that firms with high levels of financial leverage witness a lower reduction of idiosyncratic risk under a positive CSR [5].

It is generally believed that the more investment a firm makes in $\mathrm{R} \& \mathrm{D}$, the more talented researchers they will employ and the more developed equipment they will buy to invest in new products or update the old ones. By doing so, this firm can make a huge improvement in innovation and it can outperform other competitors in the market. However, the impact of R\&D investment on firms' idiosyncratic risk is still unclear in many papers.

Our research takes the Chinese stock market as research object because, compared with other developed countries, China's R\&D development is relatively backward. in recent years, more and more Chinese companies have invested more and more in $\mathrm{R} \& \mathrm{D}$, and begun to focus on the development of R\&D. [6]. In addition, the Chinese government has also introduced many policies to promote the development of $\mathrm{R} \& \mathrm{D}$, such as tax reduction and exemption policies, R\&D subsidies and direct subsidies to companies. [7]. On the other hand, China's stock market has not yet fully developed and matured, and the idiosyncratic risks of listed companies vary. Therefore, this also directly led to greater fluctuations in stock prices. In order to reduce the risk of investors, Chinese listed companies need to understand their idiosyncratic risks.

The main contributions of this paper are three points:

first, this paper is the first to investigate how R\&D investment affects firms' idiosyncratic risk. Our findings provide evidence to the notion that R\&D investment can push firms' innovation and further increase the diversification of the products, which can result in lower idiosyncratic risk. In other words, this paper expands the research depth on firms' idiosyncratic risk.

Second, this paper discusses the relationship between R\&D investment and enterprise development. $R \& D$ investment is one of the direct variables to firms' innovation, so our study expands the research on companies' innovation.

Third, this paper analyzes the heterogeneity of the relationship between firms' innovation and firms' idiosyncratic risk which increases the liability of our result. 
The remainder of this study is organized as follows. After developing our hypotheses in section 2 , we introduce our data and methodology in section 3, including sample, data source, research design and so forth. In section 4, we provide our empirical results such as descriptive statistics, correlation analysis, baseline results, additional analyses and robustness checks. Finally, we conclude the paper in section 5 .

\section{HYPOTHESIS DEVELOPMENT}

\subsection{Firm innovation and idiosyncratic risks}

For a firm, innovation is the driving force for its promotion of highquality and sustainable development, and it is also the key to its survival and development [8]. Various research findings are also of the consensus view that the development of firms is leveraged on innovation. In a dynamic environment, the innovative ability of companies is the stimulating element that help these companies to break through the bottlenecks of their development, achieve sustainable development and create benefits for interest groups [9]. In the work [10], Padgett et al. made a statement that a firm can attain a favorable competitive advantage through $\mathrm{R} \& \mathrm{D}$, as it can increase its overall net worth position

In order to comprehend in detail how R\&D can reduce a firm's idiosyncratic risk, two main aspects will be discussed further. Firstly, by investing in $\mathrm{R} \& \mathrm{D}$, the needs of stakeholders can be incorporated into the product, in this regard, they attain more benefits [11]. This can improve a company's ability to meet the stakeholders' needs and ultimately increase the company's revenue. Moreover, the risk of a company having a varied offering is reduced. Secondly, Barney tabled the position that $\mathrm{R} \& \mathrm{D}$ investment into the invention of products and processes related to the firm, as well as the creation of complicated and obscure product portfolios, results in more product variation and the risk of competitors' imitation of the company's offering minimized [12]. This not only increases the advantages for competing firms, but also their security. Resulting in the reduction of the idiosyncratic risks as well. Based on the above analysis, this article puts forward Hypothesis 1.

Hypothesis 1: There is a reverse correlation between firm innovation investment and firm idiosyncratic risk.

For innovation investment activities to be executed efficiently, they require a lot of investment as well as a large capital injection. Overinvestment into innovation will however inevitably increase the company's debt. An excessive debt ratio is often accompanied by an increase in financial risks [13]. In order to reduce risks, business operators tend to reduce high-risk innovative investment projects, thus inhibiting corporate innovation investment activities [14].

Amongst the various external financing channels, debt financing is one of the important sources of corporate investment funding, and it is particularly valuable for corporate innovation activities. Most companies need to use debt to raise sufficient funds to ensure the smooth progress of R\&D and innovation investment activities [13]. In addition, $\mathrm{Gu}$ and Zang indicated that due to information asymmetry, technological uncertainty and long investment cycles, corporate innovation is a high-risk activity, and debt financing models require stable and continuous cash flow support [14]. Creditors generally have stricter risk control requirements. As a result, debt risk control requires companies to reduce innovation input activities when debt levels are high. Czarnitzki and Kraft's stated that business operators' propensity to innovate was reduced by their debt levels. Leading to corporate innovation as well as R\&D activities being negatively impacted [15]. It is important to note that when the company's debt ratio is too high, its financial stability will decrease, and the risk of the financial crisis will increase, leading to an increase in idiosyncratic risks [16]. Based on the above analysis, this article puts forward Hypothesis 2:

Hypothesis 2: Firm innovation investment and idiosyncratic risk are positively correlated.

\section{RESEARCH DESIGN}

\subsection{Source of Sample}

All sample data in this research are taken from the China Stock Market and Accounting Research Database (CSMAR), and all A-share companies listed on the Shanghai and Shenzhen Stock Exchanges are included. Considering the integrity of the data, only data from 2010 to 2018 was utilized as samples for this study. According to the sample selection criteria in Kong's research [17], our sample excluded companies in the investment industry and companies with insufficient financial information. In addition, companies that were listed for less than one year during this period were excluded. As a result, our complete sample included 2514 firm-year observations

\subsection{Models}

To observe the effects of R\&D on idiosyncratic risk, the below model was framed:

$I V O L_{\mathrm{i}, \mathrm{t}}=\beta_{0}+\beta_{1} * \mathrm{RD}_{\mathrm{i}, \mathrm{t}}+\sum_{\mathrm{k}} \gamma_{k} \operatorname{Control}_{\mathrm{k}, \mathrm{i}, \mathrm{t}}+$ Year, firm fixed $+\varepsilon_{\mathrm{i}, \mathrm{t}}$

Where,

$I V O L_{\mathrm{i}, \mathrm{t}}$ consists of the unsystematic risk of firm $i$ in year $\mathrm{t} . \mathrm{RD}_{\mathrm{i}, \mathrm{t}}$ represents the research and development (R\&D) investment over the book value of firm $i$ 's total assets in year $t$. Control $_{k, \mathrm{i}, \mathrm{t}}$ is the set of control variables that are defined in Appendix A. A control for the firm-year dual fixed effect was incorporated, with the objective of alleviating any difficulties that could result from the exclusion of time-invariant and individual characteristics.

3.2.1 Dependent variable: IVOL.. To study the association between corporate innovation and idiosyncratic risks, we used the FamaFrench three-factor model to estimate the idiosyncratic risk [18] [19], which is shown in the Equ (2). And due to annual data being applied in the present study, the model referenced the monthly data for estimation in the model.

$R_{i, t}-r_{f, t}=\alpha_{i}+\beta_{i}^{M K T}\left(R_{m, t}-r_{f, t}\right)+\beta_{i}^{S M B} S M B_{t}+\beta_{i}^{H M L} H M L_{i}+\varepsilon_{i, t}$

Where,

$R_{\mathrm{i}, \mathrm{t}}$ stood for the stock return rate in month $t$ of $i$, while $r_{f, t}$ measured the risk-free interest rate in month $t . R_{m, t}$ was the market return in month $t$, and $S M B_{t}$ and $H M L_{t}$ is company $i$ 's size factor in month $t$. The book-to-market rate factor, $\epsilon_{\mathrm{i}, \mathrm{t}}$, is a residual item. The annualized standard deviation of the residual can then be used to calculate the annual special volatility of the company's stock as 
Table 1: Descriptive statistics for the variables applied in the analysis

\begin{tabular}{llllllll}
\hline Variables & Mean & Median & Max & Min & SD & Skewness & Kurtosis \\
\hline IVOL & 0.086 & 0.081 & 0.210 & 0.034 & 0.031 & 1.318 & 5.549 \\
RD & 0.020 & 0.017 & 0.098 & 0.000 & 0.019 & 1.545 & 6.305 \\
SIZE & 22.519 & 22.367 & 26.191 & 20.606 & 1.123 & 0.869 & 3.858 \\
TOBIN & 2.051 & 1.674 & 7.251 & 0.916 & 1.146 & 2.193 & 8.719 \\
BM & 0.596 & 0.597 & 1.092 & 0.138 & 0.227 & 0.047 & 2.231 \\
ROA & 0.047 & 0.045 & 0.190 & -0.159 & 0.049 & -0.575 & 6.686 \\
LEV & 0.376 & 0.359 & 0.839 & 0.044 & 0.199 & 0.333 & 2.254 \\
BOARD & 2.131 & 2.197 & 2.708 & 1.609 & 0.197 & -0.291 & 4.092 \\
\hline
\end{tabular}

follows:

$$
I V O L_{\mathrm{i}, \mathrm{t}}=\sqrt{\operatorname{Var}\left(\varepsilon_{\mathrm{i}, \mathrm{t}}\right)}
$$

3.2.2 Test variable: $R \& D$.. $\mathrm{R} \& \mathrm{D}$ is the test variable, which is equal to the R\&D investment over the book value of the company's total assets. Company innovation activities are a long-term sustainable behavior that is vital to the future development of an enterprise and requires a continuous investment of funds.

3.2.3 Control variables. To assess the extent of the effects of R\&D on idiosyncratic risk, the following control variables were chosen according to previous research on the latter [17]. These elements include the size of the firm (SIZE), the book-to-market ratio (BTM), the return on assets (ROA) this is the ratio of net profit in relation to total assets, the asset-liability ratio of listed companies (LEV), the ratio of total liabilities to total assets, the size of the board of directors (BOARD) which is represented by the total number of directors, and Tobin's $Q$ value (TOBIN). In addition, this paper controls as well the unvarying effects of year and individual.

\section{EMPIRICAL ANALYSES}

\subsection{Descriptive Statistics}

Table 1 displays descriptive statistics for the variables, which includes Mean, median, maximum, minimum standard deviation, skewness and kurtosis of each variable. Our dependent variable (IVOL) is calculated by Fama-French's three-factor model [18] [19]. The definitions of all variables are in Appendix A.

The descriptive statistics of the main variables are summarized in Table 1 . The average value and standard deviation of idiosyncratic risk (IVOL) are 0.068 and 0.031 respectively. This suggests that the volatility of particular risks varies widely between companies. Furthermore, the resultant statistical output of other control variables falls within the normal range. It can also be noted from the table that the company size has always been the maximum in the average, median, maximum, and minimum values. This indicates that the size of the company excludes the external environment of the market. In addition to the systemic risks, it can be concluded that the organization's size has a more significant impact on idiosyncratic risks.

\subsection{Baseline Results}

Table 2 indicates the outcomes of our regression model to verify our hypothesis. As shown in the table, the coefficient between RD and IVOL is negative, which supports our hypothesis. To be specific, the coefficient number equals -0.056 , statistically significant at the 5\% level, showing that a higher RD input may reduce firms' idiosyncratic risk. This result shows that RD investment can push the innovation of products, processes, and the creation of complicated product portfolios, so that it can further increase the product differentiation and reduce firms' idiosyncratic risk.

\section{FURTHER ANALYSISTHIS}

It is generally believed that the more financially powerful firms are more willing to invest in $\mathrm{RD}$. Therefore, we forecast that the difference of the coefficient between RD and IVOL should be more pronounced among firms with a larger gap of financial ability. Then we classify our sample firms according to 4 criteria in order to distinguish their financial condition: firms' market value, whether it is a state-owned enterprise, the level of leverage, and whether it is audited by the Big Four.

\subsection{Firms' market value}

In the first two columns of table 3, we classify the firms into 2 subsets: firms with a low market value and firms with a high market value. To be specific, the coefficient result of $\mathrm{RD}$ in firms with low market value is -0.079 , significant at the $5 \%$ level. In comparison, the coefficient result of RD in firms with high market value is -0.038 and is not significant. This outcome demonstrates that the influence of $\mathrm{RD}$ investment is larger in firms with a lower market value. Because firms with lower market value are generally in the early stage and do not have many mature products, so they have a greater potential to improve. In this stage, every little input into the RD may lead to a great change, so the influence is more profound in the firms with a low market value.

\subsection{State-owned enterprise}

In the last two columns of table 3 , we classify the firms into 2 subsets: non-state-owned firms and state-owned firms. To be specific, the coefficient result of RD in non-state-owned firms is - 0.064 , significant at the $5 \%$ level. In comparison, the coefficient result of $\mathrm{RD}$ in state-owned firms is -0.023 and is not significant. This outcome demonstrates that the influence of $\mathrm{RD}$ investment is larger in firms that are non-state-owned. Since state-owned firms can receive more sufficient financial support from the government, non-state-owned firms are generally less powerful and left behind by state-owned firms, so they have a greater potential to improve. In this case, every 
Table 2: The results for the regression of the impact of $R \& D$ investment on firms' idiosyncratic risk, using the full sample. Meanwhile, we control other potentially influential variables.

\begin{tabular}{cc}
\hline Ef & Dependent variable $=I V O L$ \\
\hline SIZE & $-0.056^{* *}$ \\
& $(-2.330)$ \\
tobin & 0.000 \\
& $(0.351)$ \\
BTM & $0.001^{* * *}$ \\
& $(2.841)$ \\
ROA & $-0.020^{* * *}$ \\
& $(-8.050)$ \\
LEV & $0.027^{* * *}$ \\
& $(3.818)$ \\
BOARD & $-0.005^{*}$ \\
& $(-1.920)$ \\
cons & $0.004^{*}$ \\
& $(1.754)$ \\
Year fixed effects & $0.092^{* * *}$ \\
Firm fixed effects & $(5.427)$ \\
Observations & Yes \\
Adjusted & Yes \\
& 14891 \\
& 0.344
\end{tabular}

little input into the RD may lead to a great change, so the influence is more profound in the non-state-owned firms.

\subsection{Leverage level}

In the first two columns of table 4 , we classify the firms into 2 subsets: low leverage firms and high leverage firms. The statistical data from the table indicates the coefficient result of RD in low leverage firms is -0.083 , significant at the $5 \%$ level. In comparison, the coefficient result of RD in high leverage firms is -0.020 and is not significant. This outcome demonstrates that the influence of $\mathrm{RD}$ investment is larger in firms with a lower leverage level. Since liability accounts for a higher proportion of the total asset in the low leverage firms, the risk is higher and these firms are generally in the early stage, so they have a greater potential to improve. In this case, every little input into the RD may lead to a great change, so the influence is more profound in the low leverage firms.

\subsection{Big Four}

In the last two columns of table 4 , we classify the firms into 2 subsets: firms not audited by the auditors from Big Four and firms audited by the auditors from Big Four. In detail, according to the statistical outsomes, the coefficient result of RD in firms not audited by the auditors from Big Four is -0.064 , significant at the 5\% level In comparison, the coefficient result of $\mathrm{RD}$ in firms audited by the auditors from Big Four is 0.084 and is not significant. This outcome demonstrates that the influence of $\mathrm{RD}$ investment is larger in firms that are not Big Four. Since the cost to hire auditors from Big Four is high, small firms cannot afford it, so firms that are not audited by Big Four can stand for small companies. In small firms, every little input into the RD may lead to a great change, so the influence is more profound in the firms that are not audited by the Big Four.

We find that the gap between the coefficients of RD regard to Big Four firms' idiosyncratic risk is the largest. Specifically, in table $4(3)$ (4), the coefficient of RD with non- Big Four firms is negative $(-0.064)$ while its counterpart with Big Four firms is positive (0.084), which generates the biggest difference among the 4 classification conditions.

*** indicates significance at the $1 \%$ level (two-tailed)

\section{ROBUSTNESS CHECKS}

As is shown in table 5, in order to test the robustness of our regression results and eliminate the interference of other endogenous factors, we conduct a variety of robustness tests, including replacing the $\mathrm{RD}$ value and adding lag terms. We replace the $\mathrm{RD}$ value by taking the logarithm of the RD value to illustrate the general relationship between $\mathrm{RD}$ investment and firms' idiosyncratic risk. In order to exclude the effects of endogenous factors, we add two lag terms: RD_L1 and RD_L2. We notice that the coefficients of all the new factors are still negative, which is the same as the analysis we discussed above. Therefore, these results prove the robustness of our hypothesis.

\section{CONCLUSION}

Based on a sample of all the Shanghai and Shenzhen Stock Exchanges companies from 2010 to 2018 , this paper study the influence of RD level on firms' idiosyncratic risk. Based on the data analysis, the RD level is negatively related to firms' idiosyncratic risk after controlling other variables. The empirical results show that a higher RD investment level can reduce firms' idiosyncratic 
Table 3: The results of regression of the impact of $R \& D$ investment on firms' idiosyncratic risk by dividing the full sample into two groups based on two mechanisms: the market value of firms and whether it is a state-owned firm.

\begin{tabular}{|c|c|c|c|c|}
\hline & $\begin{array}{l}\text { )1( } \\
\text { Low market value }\end{array}$ & $\begin{array}{l}2( \\
\text { High market value }\end{array}$ & $\begin{array}{l}\text { )3( } \\
\text { non-state-owned }\end{array}$ & $\begin{array}{l}\text { )4( } \\
\text { state-owned }\end{array}$ \\
\hline $\mathrm{RD}$ & $\begin{array}{l}-0.079^{* *} \\
(-1.968)\end{array}$ & $\begin{array}{l}-0.038 \\
(-1.330)\end{array}$ & $\begin{array}{l}-0.064^{* *} \\
(-2.240)\end{array}$ & $\begin{array}{l}-0.023 \\
(-0.556)\end{array}$ \\
\hline SIZE & $\begin{array}{l}-0.000 \\
(-0.094)\end{array}$ & $\begin{array}{l}-0.000 \\
(-0.513)\end{array}$ & $\begin{array}{l}0.002^{* *} \\
(1.992)\end{array}$ & $\begin{array}{l}0.000 \\
(0.065)\end{array}$ \\
\hline tobin & $\begin{array}{l}0.001 \\
(1.342)\end{array}$ & $\begin{array}{l}0.001 \\
(0.962)\end{array}$ & $\begin{array}{l}0.001 \\
(1.398)\end{array}$ & $\begin{array}{l}0.001 \\
(1.578)\end{array}$ \\
\hline BTM & $\begin{array}{l}-0.020^{* * *} \\
(-5.173)\end{array}$ & $\begin{array}{l}-0.023^{* * *} \\
(-6.849)\end{array}$ & $\begin{array}{l}-0.022^{* * *} \\
(-7.336)\end{array}$ & $\begin{array}{l}-0.022^{* * *} \\
(-5.003)\end{array}$ \\
\hline ROA & $\begin{array}{l}0.019^{*} \\
(1.882)\end{array}$ & $\begin{array}{l}0.035^{* * *} \\
(3.404)\end{array}$ & $\begin{array}{l}0.014^{*} \\
(1.664)\end{array}$ & $\begin{array}{l}0.050^{* * *} \\
(3.458)\end{array}$ \\
\hline LEV & $\begin{array}{l}-0.009^{* *} \\
(-2.140)\end{array}$ & $\begin{array}{l}0.003 \\
(0.840)\end{array}$ & $\begin{array}{l}-0.009^{* * *} \\
(-2.792)\end{array}$ & $\begin{array}{l}0.012^{* *} \\
(2.240)\end{array}$ \\
\hline BOARD & $\begin{array}{l}0.007^{* *} \\
(2.250)\end{array}$ & $\begin{array}{l}0.001 \\
(0.233)\end{array}$ & $\begin{array}{l}0.004 \\
(1.518)\end{array}$ & $\begin{array}{l}0.003 \\
(0.803)\end{array}$ \\
\hline - & $\begin{array}{l}0.104^{* * *} \\
(3.549)\end{array}$ & $\begin{array}{l}0.107^{* * *} \\
(4.989)\end{array}$ & $\begin{array}{l}0.068^{* * *} \\
(3.416)\end{array}$ & $\begin{array}{l}0.076^{* *} \\
(2.379)\end{array}$ \\
\hline Adjusted & 0.327 & 0.389 & 0.354 & 0.336 \\
\hline
\end{tabular}

The numbers in parentheses are the $\mathrm{t}$ values.

${ }^{*}$ indicates significance at the $10 \%$ level (two-tailed)

** indicates significance at the $5 \%$ level (two-tailed)

*** indicates significance at the $1 \%$ level (two-tailed)

Table 4: The results of regression of the impact of $R \& D$ investment on firms' idiosyncratic risk by dividing the full sample into two groups based on two mechanisms: the leverage level of and whether it is audited by the Big Four.

\begin{tabular}{|c|c|c|c|c|}
\hline & $\begin{array}{l}\text { (1) } \\
\text { Low leverage }\end{array}$ & $\begin{array}{l}(2) \\
\text { High leverage }\end{array}$ & $\begin{array}{l}(3) \\
\text { Non-Big Four }\end{array}$ & $\begin{array}{l}\text { (4) } \\
\text { Big Four }\end{array}$ \\
\hline $\mathrm{RD}$ & $\begin{array}{l}-0.083^{* *} \\
(-2.320)\end{array}$ & $\begin{array}{l}-0.020 \\
(-0.622)\end{array}$ & $\begin{array}{l}-0.064^{* * *} \\
(-2.624)\end{array}$ & $\begin{array}{l}0.084 \\
(0.814)\end{array}$ \\
\hline SIZE & $\begin{array}{l}0.000 \\
(0.376)\end{array}$ & $\begin{array}{l}0.000 \\
(0.138)\end{array}$ & $\begin{array}{l}0.001 \\
(0.750)\end{array}$ & $\begin{array}{l}-0.014^{* *} \\
(-2.458)\end{array}$ \\
\hline tobin & $\begin{array}{l}0.001^{* *} \\
(2.250)\end{array}$ & $\begin{array}{l}0.001 \\
(1.372)\end{array}$ & $\begin{array}{l}0.001^{* * *} \\
(2.731)\end{array}$ & $\begin{array}{l}0.002 \\
(1.369)\end{array}$ \\
\hline BTM & $\begin{array}{l}-0.015^{* * *} \\
(-4.001)\end{array}$ & $\begin{array}{l}-0.028^{* * *} \\
(-7.649)\end{array}$ & $\begin{array}{l}-0.021^{* * *} \\
(-8.151)\end{array}$ & $\begin{array}{l}-0.041^{* * *} \\
(-3.183)\end{array}$ \\
\hline $\mathrm{ROA}$ & $\begin{array}{l}0.028^{* * *} \\
(2.750)\end{array}$ & $\begin{array}{l}0.019^{*} \\
(1.925)\end{array}$ & $\begin{array}{l}0.023^{* * *} \\
(3.248)\end{array}$ & $\begin{array}{l}0.073^{* *} \\
(2.142)\end{array}$ \\
\hline LEV & $\begin{array}{l}-0.000 \\
(-0.066)\end{array}$ & $\begin{array}{l}-0.006 \\
(-1.556)\end{array}$ & $\begin{array}{l}-0.006^{*} \\
(-1.900)\end{array}$ & $\begin{array}{l}0.018 \\
(0.988)\end{array}$ \\
\hline BOARD & $\begin{array}{l}0.004 \\
(1.283)\end{array}$ & $\begin{array}{l}0.004 \\
(1.486)\end{array}$ & $\begin{array}{l}0.004^{*} \\
(1.692)\end{array}$ & $\begin{array}{l}-0.006 \\
(-0.710)\end{array}$ \\
\hline _cons & $\begin{array}{l}0.090^{* * *} \\
(3.326)\end{array}$ & $\begin{array}{l}0.095^{* * *} \\
(4.187)\end{array}$ & $\begin{array}{l}0.087^{* * *} \\
(5.017)\end{array}$ & $\begin{array}{l}0.435^{* * *} \\
(3.140)\end{array}$ \\
\hline Adjusted & 0.355 & 0.340 & 0.348 & 0.379 \\
\hline
\end{tabular}

The numbers in parentheses are the $t$ values.

*indicates significance at the $10 \%$ level (two-tailed)

${ }^{* *}$ indicates significance at the $5 \%$ level (two-tailed) 
Table 5: The results for the regression between firms' idiosyncratic risk and alternative variables (replacing RD). We include lag terms: RD_L1 and RD_L2, stand for RD investment 1 year before and 2 years before respectively, and take logarithm of the RD values as well as the lag terms: lnRDspend, InRDspend_L1 and lnRDspend_L2

\begin{tabular}{|c|c|c|c|c|c|}
\hline & $\begin{array}{l}\text { )1( } \\
\text { IVOL }\end{array}$ & $\begin{array}{l}\text { )2( } \\
\text { IVOL }\end{array}$ & $\begin{array}{l}\text { )3( } \\
\text { IVOL }\end{array}$ & $\begin{array}{l}\text { )4( } \\
\text { IVOL }\end{array}$ & $\begin{array}{l}\text { (5) } \\
\text { IVOL }\end{array}$ \\
\hline RD_L1 & $\begin{array}{l}-0.051^{* *} \\
(-2.092)\end{array}$ & & & & \\
\hline RD_L2 & & $\begin{array}{l}-0.052^{*} \\
(-1.894)\end{array}$ & & & \\
\hline lnRDspend & & & $\begin{array}{l}-0.001^{* *} \\
(-2.190)\end{array}$ & & \\
\hline lnRDspend_L1 & & & & $\begin{array}{l}-0.002^{* * *} \\
(-5.501)\end{array}$ & \\
\hline lnRDspend_L2 & & & & & $\begin{array}{l}-0.001^{* * *} \\
(-3.400)\end{array}$ \\
\hline SIZE & $\begin{array}{l}0.005^{* * *} \\
(7.974)\end{array}$ & $\begin{array}{l}0.006^{* * *} \\
(7.189)\end{array}$ & $\begin{array}{l}0.001 \\
(1.091)\end{array}$ & $\begin{array}{l}0.007^{* * *} \\
(7.733)\end{array}$ & $\begin{array}{l}0.006^{* * *} \\
(6.563)\end{array}$ \\
\hline tobin & $\begin{array}{l}0.001^{* * *} \\
(3.458)\end{array}$ & $\begin{array}{l}0.001^{* * *} \\
(2.948)\end{array}$ & $\begin{array}{l}0.001^{* *} \\
(2.087)\end{array}$ & $\begin{array}{l}0.001^{* *} \\
(2.189)\end{array}$ & $\begin{array}{l}0.001^{* *} \\
(2.198)\end{array}$ \\
\hline BTM & $\begin{array}{l}-0.038^{* * *} \\
(-16.781)\end{array}$ & $\begin{array}{l}-0.039^{* * *} \\
(-15.044)\end{array}$ & $\begin{array}{l}-0.020^{* * *} \\
(-7.238)\end{array}$ & $\begin{array}{l}-0.036^{* * *} \\
(-13.528)\end{array}$ & $\begin{array}{l}-0.038^{* * *} \\
(-12.464)\end{array}$ \\
\hline ROA & $\begin{array}{l}0.004 \\
(0.723)\end{array}$ & $\begin{array}{l}-0.003 \\
(-0.524)\end{array}$ & $\begin{array}{l}0.030^{* * *} \\
(3.684)\end{array}$ & $\begin{array}{l}0.001 \\
(0.180)\end{array}$ & $\begin{array}{l}-0.006 \\
(-0.725)\end{array}$ \\
\hline LEV & $\begin{array}{l}-0.001 \\
(-0.347)\end{array}$ & $\begin{array}{l}-0.001 \\
(-0.182)\end{array}$ & $\begin{array}{l}-0.005 \\
(-1.556)\end{array}$ & $\begin{array}{l}-0.002 \\
(-0.538)\end{array}$ & $\begin{array}{l}-0.001 \\
(-0.303)\end{array}$ \\
\hline BOARD & $\begin{array}{l}0.002 \\
(0.766)\end{array}$ & $\begin{array}{l}0.001 \\
(0.261)\end{array}$ & $\begin{array}{l}0.005^{* *} \\
(2.095)\end{array}$ & $\begin{array}{l}0.002 \\
(0.881)\end{array}$ & $\begin{array}{l}0.001 \\
(0.303)\end{array}$ \\
\hline _cons & $\begin{array}{l}-0.018 \\
(-1.265)\end{array}$ & $\begin{array}{l}-0.029^{*} \\
(-1.650)\end{array}$ & $\begin{array}{l}0.093^{* * *} \\
(4.751)\end{array}$ & $\begin{array}{l}-0.014 \\
(-0.764)\end{array}$ & $\begin{array}{l}-0.019 \\
(-0.906)\end{array}$ \\
\hline $\mathrm{N}$ & 9777 & 7709 & 12580 & 9777 & 7709 \\
\hline $\mathrm{r} 2$ & 0.489 & 0.508 & 0.349 & 0.491 & 0.509 \\
\hline Adjusted & 0.337 & 0.360 & 0.348 & 0.490 & 0.509 \\
\hline
\end{tabular}

The numbers in parentheses are the $t$ values.

*indicates significance at the $10 \%$ level (two-tailed)

** indicates significance at the $5 \%$ level (two-tailed)

${ }^{* * *}$ indicates significance at the $1 \%$ level (two-tailed)

risk. Moreover, the impact of RD investment on firms' idiosyncratic risk is more pronounced in firms with small market capitalization, non-state-owned, low leverage and non-Big 4 auditing. In addition, we take the logarithm of $\mathrm{RD}$ values to replace the previous variable and add lag terms to test the robustness, and the results prove the robustness of our conclusion.

Overall, our findings provide evidence to the conclusion that $\mathrm{RD}$ input appears to reduce firms' idiosyncratic risk, which is beneficial to the market. In reality, however, most of the small companies spend most of the money on supporting the daily operation instead of $\mathrm{RD}$ investment. In this case, the government seems to have the responsibility to provide subsidies to these companies that are still in the early stage, to support them achieve innovation and reduce their idiosyncratic risk.

\section{REFERENCES}

[1] Tohidi, H., \& Jabbari, M. M. (2012). The important of innovation and its crucial role in growth, survival and success of organizations. Procedia Technology, 1,
535-538.

[2] Urbancova, H. (2013). Competitive advantage achievement through innovation and knowledge. fournal of competitiveness, 5(1).

[3] Luo, X., \& Bhattacharya, C. B. (2009). The debate over doing good: Corporate social performance, strategic marketing levers, and firm-idiosyncratic risk. Journal of Marketing, 73(6), 198-213.

[4] Mishra, S., \& Modi, S. B. (2013). Positive and negative corporate social responsibility, financial leverage, and idiosyncratic risk. Journal of business ethics, 117(2), 431-448.

[5] Panousi, V., \& Papanikolaou, D. (2012). Investment, idiosyncratic risk, and ownership. The Journal of finance, 67(3), 1113-1148.

[6] Fabre, G., \& Grumbach, S. (2012). The World upside down, China's R\&D and innovation strategy.

[7] Liu, F. C., Simon, D. F., Sun, Y. T., \& Cao, C. (2011). China's innovation policies: Evolution, institutional structure, and trajectory. Research Policy, 40(7), 917-931.

[8] Lin, W. L., Mohamed, A. B., Sambasivan, M., \& Yip, N. (2020). Effect of green innovation strategy on firm-idiosyncratic risk: A competitive action perspective. Business Strategy and the Environment, 29(3), 886-901

[9] Harrison, J.S.; Bosse, D.A.; Phillips, R.A. Managing for stakeholders, stakeholder utility functions, and competitive advantage. Strateg. Manag. F. 2010, 31, 58-74

[10] Padgett, R.C.; Galan, J.I. The Effect of R\&D Intensity on Corporate Social Responsibility. J. Bus. Ethics 2010, 93, 407-418. 
Table 6: Variable definitions

\begin{tabular}{ll}
\hline Variables & Definitions \\
\hline IVOL & $\beta_{0}+\beta_{1} * \mathrm{RD}_{\mathrm{i}, \mathrm{t}}+\sum_{\mathrm{k}} \gamma \mathrm{kControl}, \mathrm{k}, \mathrm{t}+$ Year, individual (firm - level) effects model $+\varepsilon_{\mathrm{i}, \mathrm{t}}$ \\
$\mathrm{RD}$ & $\mathrm{R} \& \mathrm{D}$ investment /book value of total assets \\
SIZE & The natural logarithm of total assets at the end of the period \\
TOBIN & The ratio of listed firms' market value to book value of total assets. \\
BM & Book-to-market ratio, calculated as the book value of equity divided by the market value of equity. \\
ROA & Net profit after tax / total assets \\
LEV & Total liabilities/total assets \\
BOARD & Total number of directors \\
\hline
\end{tabular}

[11] Orlitzky, M.; Schmidt, F.L.; Rynes, S.L. Corporate Social and Financial Performance: A Meta-Analysis.Organ. Stud. 2003, 24, 403-441.

[12] Barney, J. Firm Resources and Sustained Competitive Advantage. J. Manag. 1991, 17, 99-120./

[13] Liu, D., Wan, D.L., \& Wu, Z.G. (2015). Can debt financing play a governance role in R\&D activities?(In Chinese). Journal of Xi'an Jiaotong University (Social Science Edition), (2015 03), 53-58.

[14] Gu, S.Z., \& Zhuang, Q.Q. (2016). Research on Enterprise Innovation and Development from the Perspective of Capital Market Function (In Chinese). China Soft Science, 11 .

[15] Czarnitzki, D., \& Kraft, K. (2009). Capital control, debt financing and innovative activity. Journal of Economic Behavior \& Organization, 71(2), 372-383.

[16] Malkiel, B. G., \& Xu, Y. (2002). Idiosyncratic risk and security returns. University of Texas at Dallas (November 2002).
[17] Kong, X., Pan, Y., Sun, H., \& Taghizadeh-Hesary, F. (2020). Can Environmental Corporate Social Responsibility Reduce Firms' Idiosyncratic Risk? Evidence From China. Frontiers in Environmental Science

[18] Ang, A., Hodrick, R. J., Xing, Y., \& Zhang, X. (2006). The cross-section of volatility and expected returns. The Journal of Finance, 61(1), 259-299.

[19] Tzouvanas, P., Kizys, R., Chatziantoniou, I., \& Sagitova, R. (2020). Environmental and financial performance in the European manufacturing sector: An analysis of extreme tail dependency. The British Accounting Review, 52(6), 100863.

\section{A APPENDICES}

